\title{
PENGENALAN AKTIVITAS MANUSIA DAN PEMBUATAN LOG OTOMATIS DARI REKAMAN VIDEO MENGGUNAKAN MULTILAYER PERCEPTRON
}

\author{
Lina $^{1}$, Jason $\mathrm{Su}^{2}$, Daniel Ajienegoro ${ }^{3}$ \\ 1,2 Program Studi Teknik Informatika, Universitas Tarumanagara Jakarta \\ Email: lina@untar.ac.id, j57450n@gmail.com \\ ${ }^{3}$ Profesional Teknik Industri, Perusahaan Swasta, Jakarta \\ Email:daniel.a7le@gmail.com
}

Masuk: 07-06-2021, revisi: 17-09-2021, diterima untuk diterbitkan: 17-09-2021

\begin{abstract}
ABSTRAK
Kemajuan teknologi memungkinkan kegiatan pengawasan terhadap lingkungan menjadi lebih mudah yaitu dengan melakukan pemasangan peralatan rekam yang dapat ditempatkan pada lokasi-lokasi strategis tertentu. Keberadaan peralatan teknologi ini juga membawa perubahan dalam proses analisis terhadap rekaman video maupun gambar yang telah didapatkan. Proses pengolahan terhadap video rekaman tidak lagi menggunakan cara manual, namun dapat dilakukan secara otomatis dengan menggunakan teknologi pengolahan citra dan kecerdasan buatan. Berdasarkan rekaman video maupun gambar yang diperoleh, analisis dapat dilakukan untuk mengawasi keamanan lokasi, mencatat perubahan kondisi objek tertentu, mengenali aktivitas manusia pada saat tertentu, dan lain sebagainya. Makalah ini membahas pengembangan sebuah sistem pengenalan aktivitas manusia secara otomatis berdasarkan rekaman video menggunakan metode Multilayer Perceptron. Rekaman video sebelumnya akan dicacah menjadi kumpulan citra yang kemudian diproses dengan algoritma Multilayer Perceptron untuk proses pengenalannya. Luaran dari sistem aplikasi yang dirancang berupa pengenalan aktivitas yang dilakukan manusia pada waktu tertentu dan pencatatan aktivitas tersebut dalam sebuah log dengan timestamp tertentu. Dalam makalah ini, terdapat lima jenis aktivitas manusia yang dapat dikenali secara otomatis oleh sistem, yaitu mengangkat tangan, bertepuk tangan, berdiri, duduk, dan belajar. Hasil pengujian menunjukkan bahwa keberhasilan pendeteksian aktivitas manusia dengan metode Multilayer Perceptron memiliki tingkat akurasi $97.45 \%$ untuk dataset citra yang diperoleh secara bebas dari internet, sedangkan untuk dataset citra yang dikumpulkan dengan IP Camera memiliki tingkat akurasi sebesar $100 \%$.
\end{abstract}

Kata Kunci: Pengenalan aktivitas manusia; rekaman video; Multilayer Perceptron.

\begin{abstract}
Advances in technology have made it easier to surveillance purpose by installing recording equipment that can be placed in certain strategic locations. The existence of this technology also brings changes in the analysis phase of video recordings and images that have been obtained. The processing of recorded videos no longer uses manual methods but can be done automatically using image processing and artificial intelligence algorithms. Based on the obtained video recordings, analysis can be carried out for surveillance purpose, object tracking, human activity recognition, etc. This paper discusses the development of an automatic human activity recognition system based on video recordings using Multilayer Perceptron method. The recorded video will be transformed into a collection of images which are then processed with the Multilayer Perceptron algorithm for the recognition process. The output of the designed system is the recognition of activities carried out by humans at a certain time and saved them in a log with a certain timestamp. In this paper, there are five types of human activities that can be recognized automatically by the system, namely raising hands, clapping, standing, sitting, and studying. The experimental results show that the accuracy rate of the proposed system achieved $97.45 \%$ for image datasets obtained freely from the internet, while $100 \%$ accuracy was obtained for image datasets collected with IP Cameras.
\end{abstract}

Keywords: Human activity recognition; video recording; Multilayer Perceptron. 


\section{PENDAHULUAN}

Teknologi modern memungkinkan aktivitas manusia untuk dimonitor dan diamati tanpa kehadiran manusia lain. Alat perekam video dapat memantau berbagai aktivitas yang terjadi di tempatnya terpasang. Pengawasan terhadap apa yang terjadi pada rekaman video sangat penting untuk dapat melihat perkembangan atau kegiatan yang terjadi pada waktu perekaman tersebut. Secara konvensional, hasil pemantauan dengan kamera perekam dapat dilihat dengan memutar ulang video yang direkam. Akan tetapi, proses pengecekan rekaman video menjadi tidak efisien dan tidak efektif jika pemantau harus menonton rekaman setiap detiknya. Oleh karena itu, dalam penelitian ini diusulkan untuk mengembangkan sistem yang dapat mengenali aktivitas seseorang berdasarkan rekaman video secara otomatis, serta dapat menghasilkan catatan log dari rangkaian aktivitas yang ditemukan dalam rekaman video.

Pengenalan aktivitas manusia secara luas dapat diklasifikasikan menjadi dua kategori: pengenalan berbasis visi dan pengenalan berbasis sensor. Berbagai pengenalan aktivitas berbasis sensor smartphone telah banyak dikembangkan diantaranya penggunaan sensor inersia smartphone untuk human activity recognition dengan penerapan algoritma Support Vector Machine (Wan et. al, 2019) dan Deep Learning (Ronao et. al, 2016), pengenalan berbasis visi seperti aplikasi pengenalan aktivitas manusia menggunakan Convolutional Neural Network (Prastika et. al, 2020), penggunaan algoritma Long Short Term Memory untuk pengenalan aktivitas manusia (Murad et. al, 2017), sistem pengenalan aktivitas manusia berbasis aksi, interaksi, dan gerak (Gaglio et. al, 2014; Hussain et. al, 2020), dan sistem pengenalan aktivitas berbasis skeleton data (Trinh et. al, 2015; Srivastava et. al, 2017; Komang et. al, 2019; Franco et. al, 2020). Namun demikian, pembuatan skeleton data membutuhkan proses dan waktu komputasi yang sangat lama sehingga sulit untuk diimplementasikan secara nyata di lapangan.

Dalam makalah ini, sistem pengenalan aktivitas manusia yang dikembangkan menerapkan model Multilayer Perceptron (MLP) yang merupakan bagian dari algoritma jaringan syaraf tiruan. Sistem akan melatih kumpulan data berupa frame dari video untuk setiap jenis kelas yang terdiri dari berbagai aktivitas, seperti mengangkat tangan, bertepuk tangan, berdiri, duduk, dan belajar. Sistem akan menentukan aktivitas yang terjadi pada waktu yang ditentukan. Keunggulan sistem yang dirancang dibandingkan dengan sistem yang telah ada sebelumnya adalah pendeteksian aktivitas yang dilakukan secara otomatis dan dapat dituliskan ke dalam laporan log. Laporan $\log$ akan dibagi menjadi dua jenis, yaitu laporan $\log$ detail yang berisi isi dari setiap aktivitas yang terjadi, dan laporan log timestamp yang berisi konten aktivitas dan waktu terjadinya sesuai dengan waktu yang ditentukan. Skema penulisan makalah ini mencakup pendahuluan pada bab 1, metode penelitian pada bab 2 yang membahas tentang rancangan sistem dan konsep dari model multilayer perceptron. Selanjutnya bab 3 berisi hasil dan pembahasan yang mencakup pengujian modul aplikasi dan pengujian akurasi sistem, serta bab 4 berisi kesimpulan dan saran.

\section{METODE PENELITIAN}

Sistem yang dirancang merupakan sistem yang dapat mendeteksi aktivitas-aktivitas yang terjadi pada rekaman video dengan menggunakan model Multilayer Perceptron. Sistem ini memasukkan video rekaman dan diproses untuk dicacah menjadi frame-frame yang akan diproses pendeteksian aktivitasnya oleh sistem. Aktivitas-aktivitas yang terdeteksi oleh sistem akan menghasilkan sebuah output yang berisi tulisan aktivitas yang terjadi, beserta dengan waktu terjadinya aktivitas. Jenis aktivitas dan waktu terjadinya aktivitas tersebut akan tercantum didalam suatu file log yang dapat diunduh. Alur sistem yang diusulkan menggunakan metode Multilayer Perceptron dapat dilihat pada Gambar 1. 


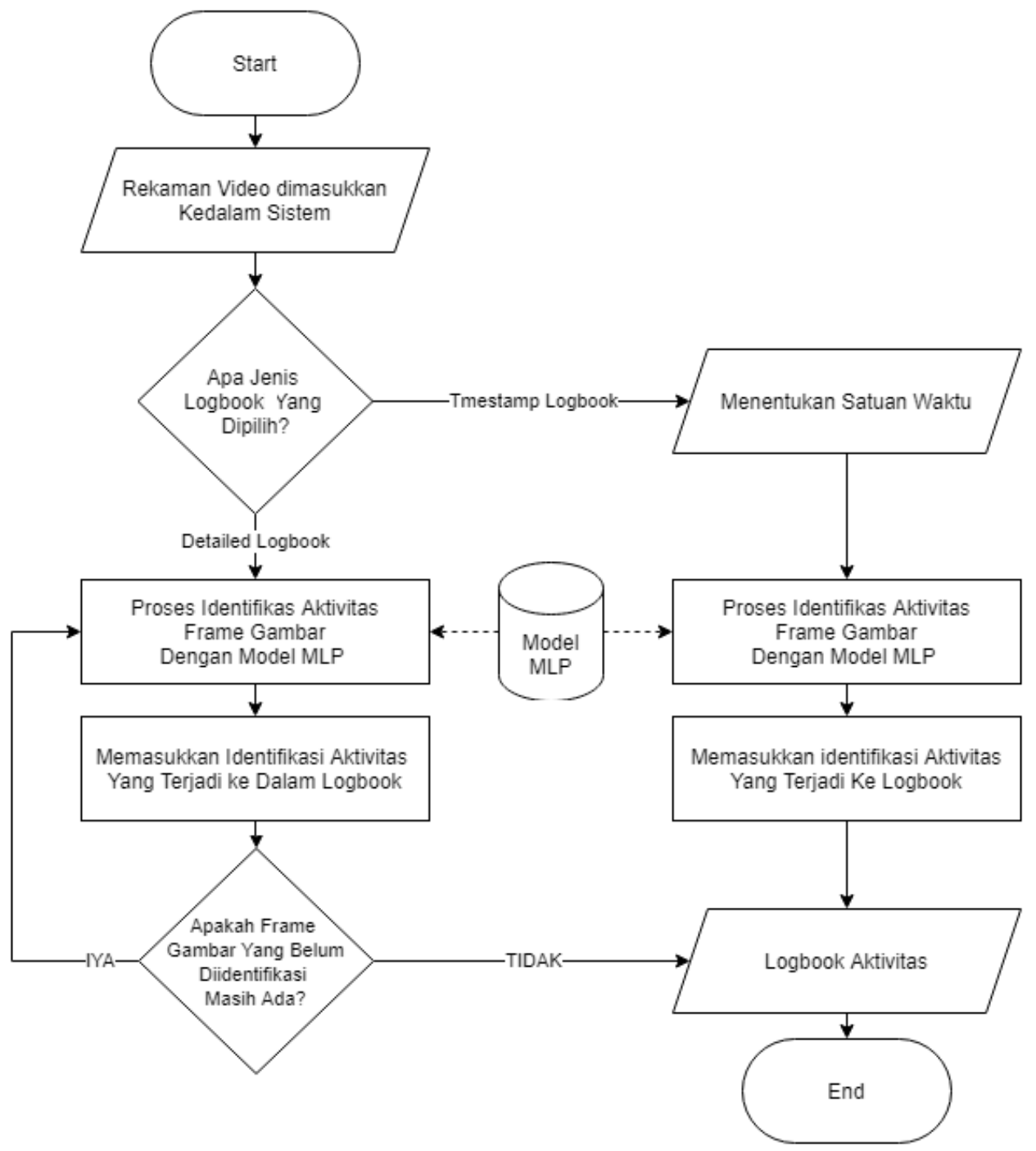

Gambar 1. Alur sistem pengenal aktivitas manusia melalui rekaman video

\section{Multilayer Perceptron}

Multilayer Perceptron adalah jenis model artificial neural network yang mempunyai hidden layer sebagai pembedaan yang paling mencolok dari pemodelan artificial neural network yang lainnya. Multilayer Perceptron terdiri dari lapisan-lapisan yang saling berhubungan, backpropagation, dan terdiri dari flatten, fungsi aktivasi sigmoid, dan fungsi softmax. Layerlayer yang saling terhubung dapat disebut juga sebagai dense layer. Multilayer Perceptron dapat menggunakan fungsi standar ReLu atau fungsi sigmoid dimana jumlah pembobotan dari sejumlah nilai masukan dan bobot bias diproses dan dimasukan kedalam activation level melalui fungsi transfer untuk mendapatkan hasil output. Keseluruhan proses setiap unit diatur dalam lapisan topologi Feed Forward Neural Network.

Secara umum, metode Multilayer Perceptron terdiri dari 3 lapisan yang saling terhubung, yaitu: 1. Input layer

Input layer yang menerima nilai masukan dari setiap data yang dimasukan. Jumlah simpul masukan harus sama dengan jumlah variabel predictor. Citra harus dikonversi menjadi vektor satu dimensi sebelum masuk ke dalam input layer. 


\section{Hidden layer}

Hidden layer melakukan transformasi nilai dari masukan yang diberikan. Simpul-simpul yang terdapat pada hidden layer saling terhubung dengan simpul-simpul pada hidden layer sebelumnya atau ke simpul-simpul yang terdapat pada output layer. Jumlah layer pada hidden layer dapat lebih dari dua layer.

\section{Output layer}

Hidden layer atau input layer terhubung oleh garis dengan output layer dan mengembalikan nilai output yang sesuai dengan variabel prediksi. Hasil output dari layer output rata-rata adalah nilai floating antara 0 sampai 1 .

Pelatihan data dengan algoritma Multilayer Perceptron paling umum menggunakan konsep backpropagation. Backpropagation merupakan proses kerja yang dilakukan secara iteratif menggunakan data pelatihan dengan cara membandingkan nilai prediksi dari jaringan dengan setiap data yang ada pada data pelatihan. Relasi yang dilakukan dengan arah mundur diterapkan dari output layer lalu ke hidden layer dan dilanjutkan ke layer pertama Pada setiap prosesnya, bobot relasi dimodifikasi untuk meminimalkan nilai Mean Squared Error antara nilai prediksi network dengan nilai yang sesungguhnya.

Fungsi aktivasi merupakan fungsi yang digunakan pada neural network untuk mengaktifkan atau tidak mengaktifkan neuron. Fungsi ReLU sangat berguna karena fungsi aktivasi dapat digunakan untuk permasalahan yang klasifikasinya tidak linier (Agarap, 2020). Fungsi ReLU dapat dihitung dengan persamaan berikut:

$$
f(x)=\left\{\begin{array}{l}
x, \text { if } x \geq 0 \\
0, \text { if } x<0
\end{array}\right.
$$

dimana $x$ merupakan nilai input dan $f(x)$ adalah nilai output.

Tahapan berikutnya adalah softmax yang merupakan fungsi aktivasi yang mengubah nilai input menjadi nilai vektor yang berjumlah 1 . Nilai input dapat positif, negatif, nol, atau lebih besar dari satu, tetapi softmax akan mengubahnya menjadi nilai antara 0 dan 1. Fungsi dari softmax adalah sebagai berikut:

$$
\sigma(z)_{i}=\frac{e^{z_{i}}}{\sum_{j=1}^{K} e^{z_{j}}}
$$

dengan $\sigma(z)_{i}$ adalah probabilitas nilai output $i, z_{i}$ adalah nilai vektor input $i, \mathrm{~K}$ jumlah kelas.

\section{HASIL DAN PEMBAHASAN}

Sistem pengenalan aktivitas manusia ini dibuat dengan menggunakan model Multilayer Perceptron untuk mengklasifikasikan dan menentukan aktivitas manusia. Pengawas rekaman video akan dimudahkan dengan sistem ini karena tidak perlu melakukan pemantauan atau menuliskan aktivitas yang terjadi pada waktu tertentu secara manual. Pengujian dilakukan pada program aplikasi dan model yang dirancang. Pengujian dilakukan untuk memastikan program dan model yang telah dibuat dapat bekerja dengan baik dan berfungsi sesuai dengan target.

\section{Pengujian program aplikasi}

Pembuatan program aplikasi dilakukan untuk memudahkan pengguna dalam melakukan proses pendeteksian aktivitas manusia dalam rekaman video. Perangkat keras yang digunakan dalam 
pembuatan aplikasi adalah prosesor CPU Intel ${ }^{\circledR}$ Core ${ }^{\mathrm{TM}}$ i5-7200U, kartu grafik GPU NVIDIA GeForce 930MX, RAM 8 GB, serta HDD 1 TB. Sedangkan perangkat lunak yang digunakan untuk pembuatan aplikasi adalah bahasa pemrograman Python 3.7 dan Visual Studio Code.

Pengujian terhadap aplikasi yang dibuat dilakukan untuk menjamin aplikasi dapat berjalan dengan baik tanpa kesalahan fungsi yang bersumber dari sistem. Adapun modul yang terdapat pada program aplikasi adalah sebagai berikut:

\section{Modul Home}

Pengujian pada modul Home dimulai dengan melakukan pengujian pada tombol yang menjalankan fungsi routing yaitu tombol Detect Activity, Timestamp Logbook, Detailed Logbook, dan tombol Help. Tampilan antarmuka modul Home dapat dilihat pada Gambar 2.

\section{Modul Detect Activity}

Pengujian pada modul Detect Activity dilakukan dengan pengujian pada fungsi routing form pada menu Home, tombol Upload yang akan mengeluarkan file dialog yang akan meminta pengguna untuk memilih video rekaman, serta tombol Timestamp yang akan menerima input jam, menit, dan detik yang diinginkan pengguna. Pengujian terakhir dilakukan pada tombol Detect untuk melakukan pengenalan aktivitas pada video rekaman yang sudah di upload sesuai waktu yang telah ditentukan pada fitur Timestamp. Hasil dari tombol Detect akan memunculkan jenis kelas aktivitas yang sedang dilakukan pada label "Aktivitas" dan memunculkan potongan citra pada waktu yang ditentukan tersebut. Tampilan antarmuka modul Detect Activity tertera pada Gambar 3.

\section{Modul Help}

Pengujian pada modul Help dilakukan dengan melakukan pengujian pada tombol routing Home untuk melihat apakah tombol tersebut dapat memindahkan pengguna ke form Home. Tampilan antarmuka modul Help dapat dilihat pada Gambar 4.

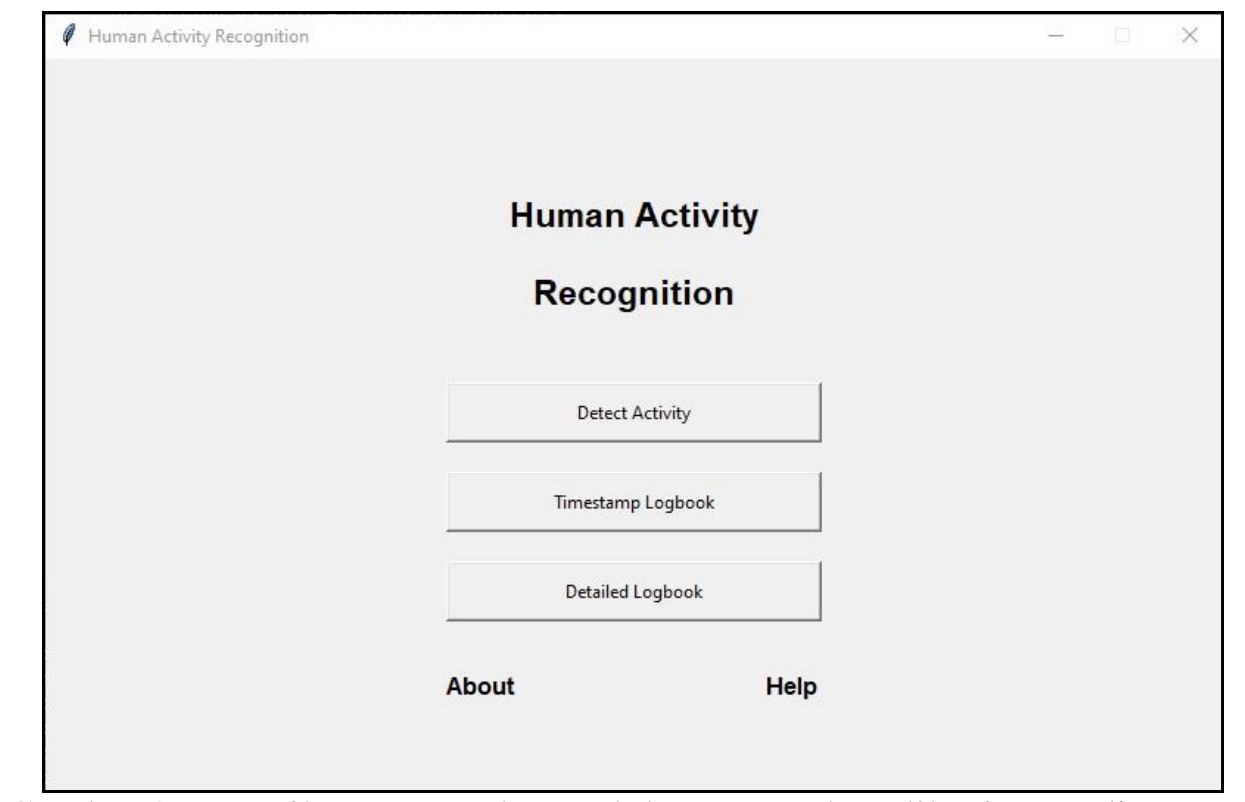

Gambar 2. Tampilan antarmuka modul Home pada aplikasi yang dirancang 


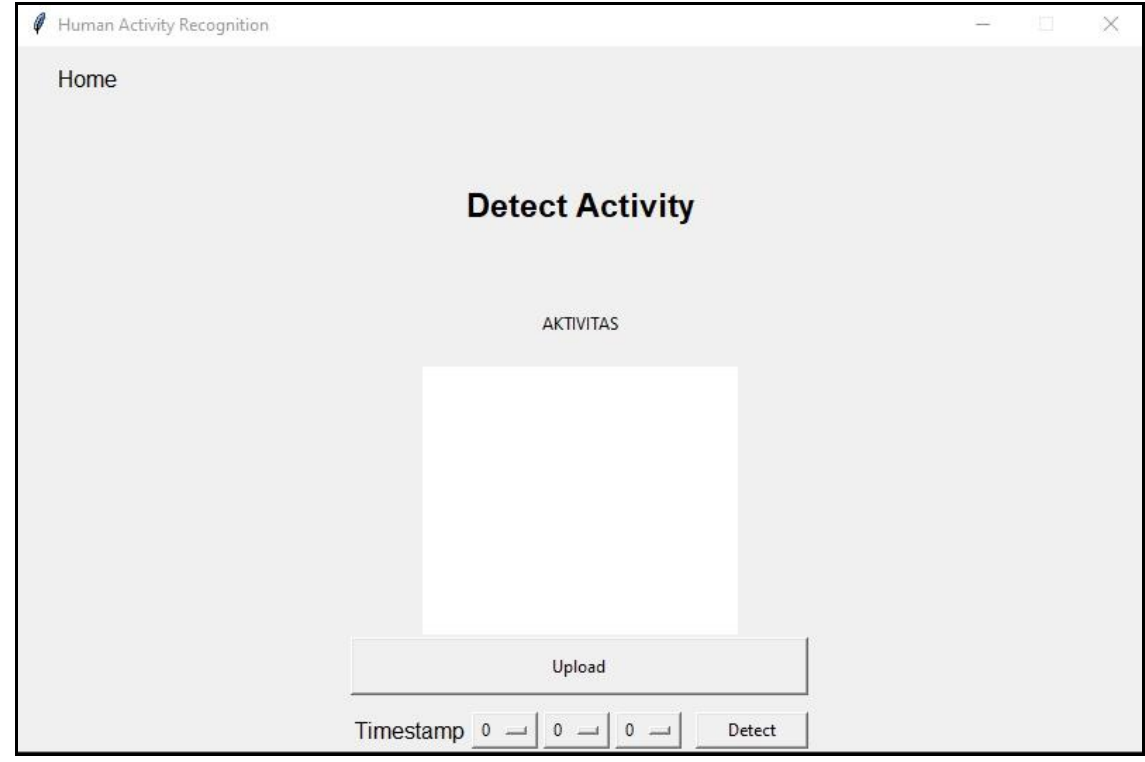

Gambar 3. Tampilan antarmuka modul Detect Activity pada aplikasi yang dirancang

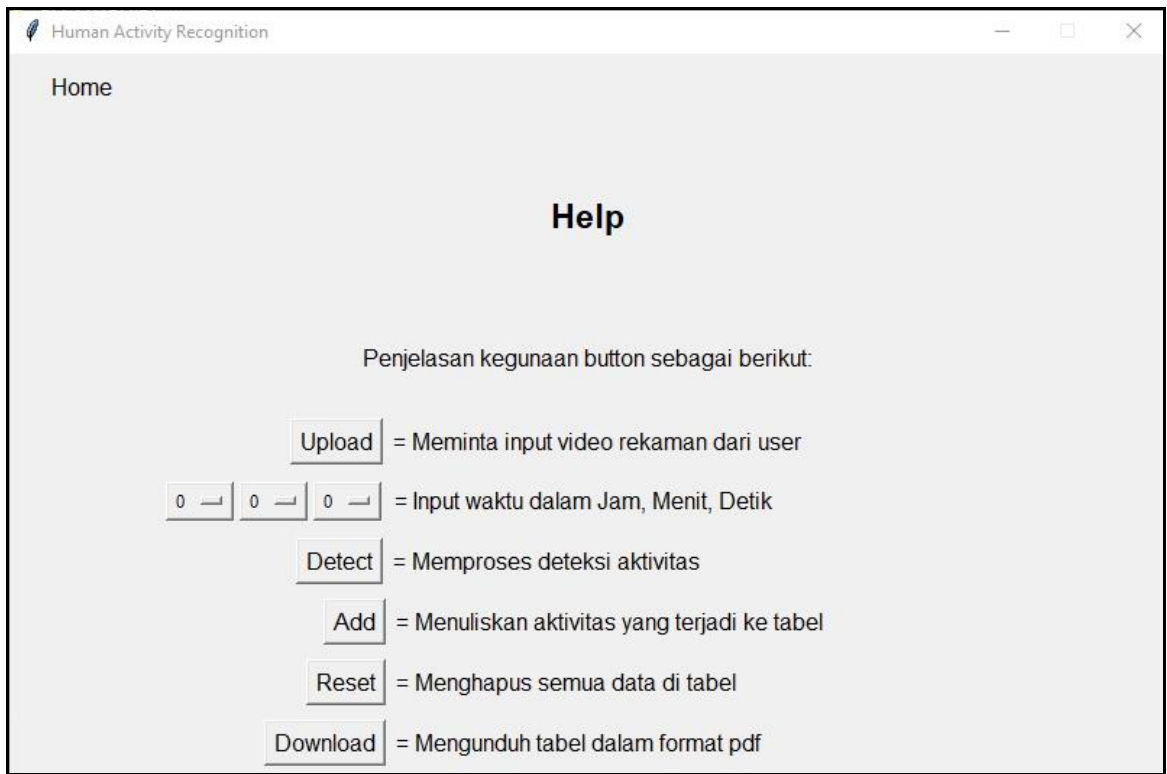

Gambar 4. Tampilan antarmuka modul Help pada aplikasi yang dirancang

\section{Pengujian model Multilayer Perceptron}

Pengujian yang dilakukan pada model Multilayer Perceptron adalah dengan membuat dua jenis dataset yaitu dataset citra tersedia dari internet dan dataset IP Camera yang citranya dikumpulkan sendiri oleh tim peneliti. Dataset citra tersedia dari internet diperoleh dengan mengumpulkan citra yang dapat diakses secara bebas di internet, sedangkan dataset IP Camera adalah dataset yang didapat dari rekaman tim peneliti dengan menggunakan IP Camera dengan resolusi $640 \times 360$ piksel yang diatur pada lokasi dan waktu tertentu. Seluruh citra yang dikumpulkan telah dipilih yang memenuhi kriteria aktivitas yang umum dilakukan di dalam ruang belajar, seperti mengangkat tangan, bertepuk tangan, berdiri, duduk, dan belajar. Contoh sampel citra dari dataset internet dapat dilihat pada Gambar 5, sedangkan contoh sampel citra dari dataset IP camera dapat dilihat pada Gambar 6. Secara detil, jumlah citra yang dikumpulkan dari masing-masing dataset untuk setiap jenis aktivitas tertera pada Tabel 1. 


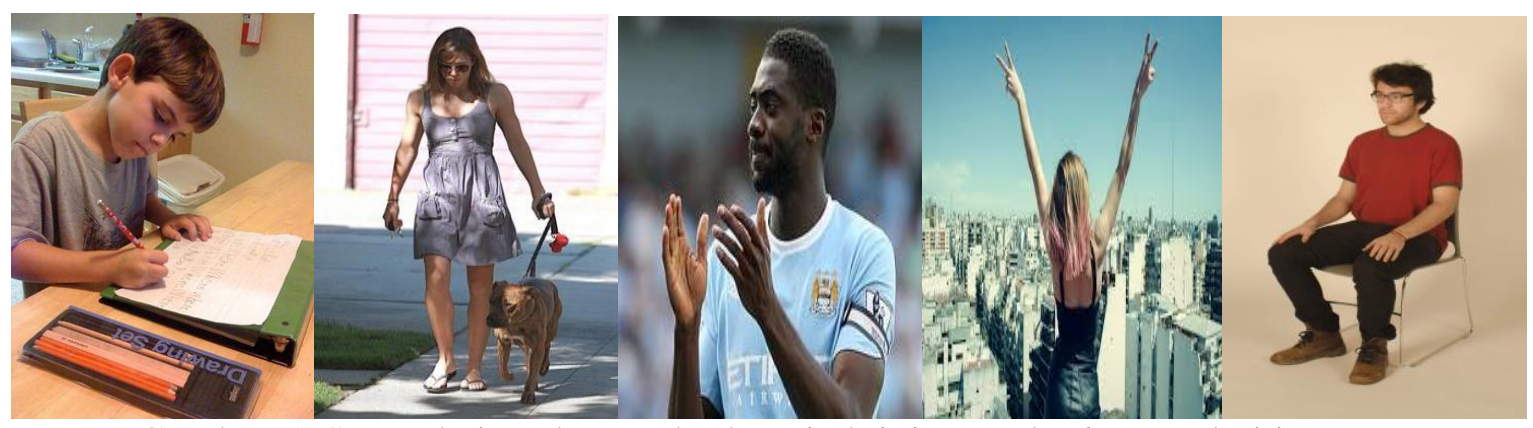

Gambar 5. Sampel citra dengan berbagai aktivitas pada dataset dari internet

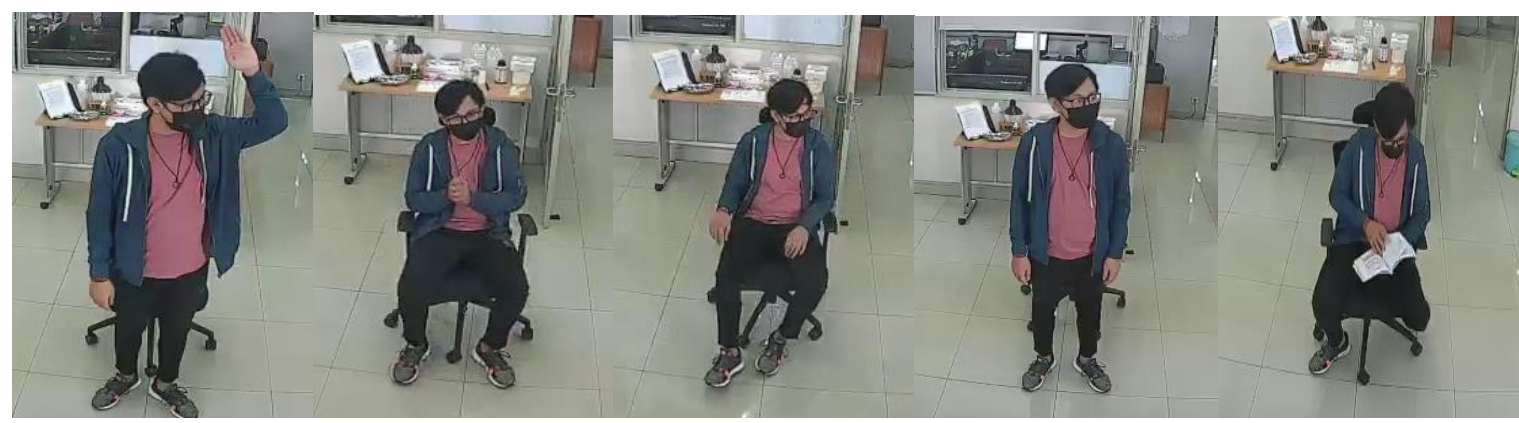

Gambar 6. Sampel citra dengan berbagai aktivitas pada dataset dari IP Camera yang dikumpulkan oleh tim peneliti

Tabel 1. Dataset Mahasiswa IP Camera

\begin{tabular}{ccc}
\hline Jenis aktivitas & $\begin{array}{c}\text { Dataset citra tersedia } \\
\text { dari internet }\end{array}$ & $\begin{array}{c}\text { Dataset citra dari } \\
\text { IP Camera }\end{array}$ \\
\hline Tepuk Tangan & 284 & 85 \\
\hline Angkat Tangan & 203 & 82 \\
\hline Duduk & 56 & 96 \\
\hline Berdiri & 598 & 126 \\
\hline Belajar & 491 & 108 \\
\hline Total & $\mathbf{1 6 3 2}$ & $\mathbf{4 9 7}$
\end{tabular}

Pengujian yang dilakukan terhadap sistem dengan Multilayer Perceptron menggunakan ukuran citra input $240 \times 240$ piksel, dengan konfigurasi ukuran batch 32, epoch 30, dan optimizer Adam. Pengujian dilakukan dengan teknik ujicoba terhadap beberapa model dengan menambahkan atau mengurangi dense layer, serta mengganti jumlah neuron atau node yang ada pada dense layer. Model yang memiliki tingkat akurasi latih dan akurasi validasi yang paling tinggi akan dipilih menjadi model yang digunakan. Arsitektur layer yang menghasilkan model terbaik dengan Multilayer Perceptron untuk kasus yang digunakan dalam percobaan tertera pada Tabel 2. 
Selanjutnya dilakukan uji coba hyperparameter terhadap model. Pengaturan konfigurasi hyperparameter diharapkan dapat menghasilkan model yang lebih baik lagi dengan mengubah ukuran batch dan banyaknya epoch yang dilakukan. Model terbaik yang dihasilkan setelah melewati proses konfigurasi yaitu, model dengan konfigurasi tertera pada Tabel 3. Grafik nilai akurasi dan loss dari arsitektur model terbaik pada Multilayer Perceptron tertera pada Gambar 7, sedangkan grafik akurasi dan loss dari model setelah konfigurasi hyperparameter pada Multilayer Perceptron dapat dilihat pada Gambar 8.

Tabel 2. Arsitektur layer yang menghasilkan model terbaik pada Multilayer Perceptron

\begin{tabular}{ccc}
\hline Flatten & $240,240,3$ & $($ None, 172800$)$ \\
\hline Dense & 1000, ReLU & $($ None, 1000$)$ \\
\hline Dense & 218, ReLU & $($ None, 218) \\
\hline Dense & 52, ReLU & $($ None, 52$)$ \\
\hline Dense & 5, Softmax & $($ None, 5$)$ \\
\hline
\end{tabular}

Tabel 3. Arsitektur layer yang menghasilkan model terbaik setelah konfigurasi hyperparameter pada Multilayer Perceptron

\begin{tabular}{ccc}
\hline Flatten & $240,240,3$ & $($ None, 172800$)$ \\
\hline Dense & 512, ReLU & $($ None, 512$)$ \\
\hline Dense & 218, ReLU & $($ None, 218) \\
\hline Dense & 5, Softmax & $($ None, 5$)$ \\
\hline Flatten & $240,240,3$ & (None, 172800) \\
\hline
\end{tabular}
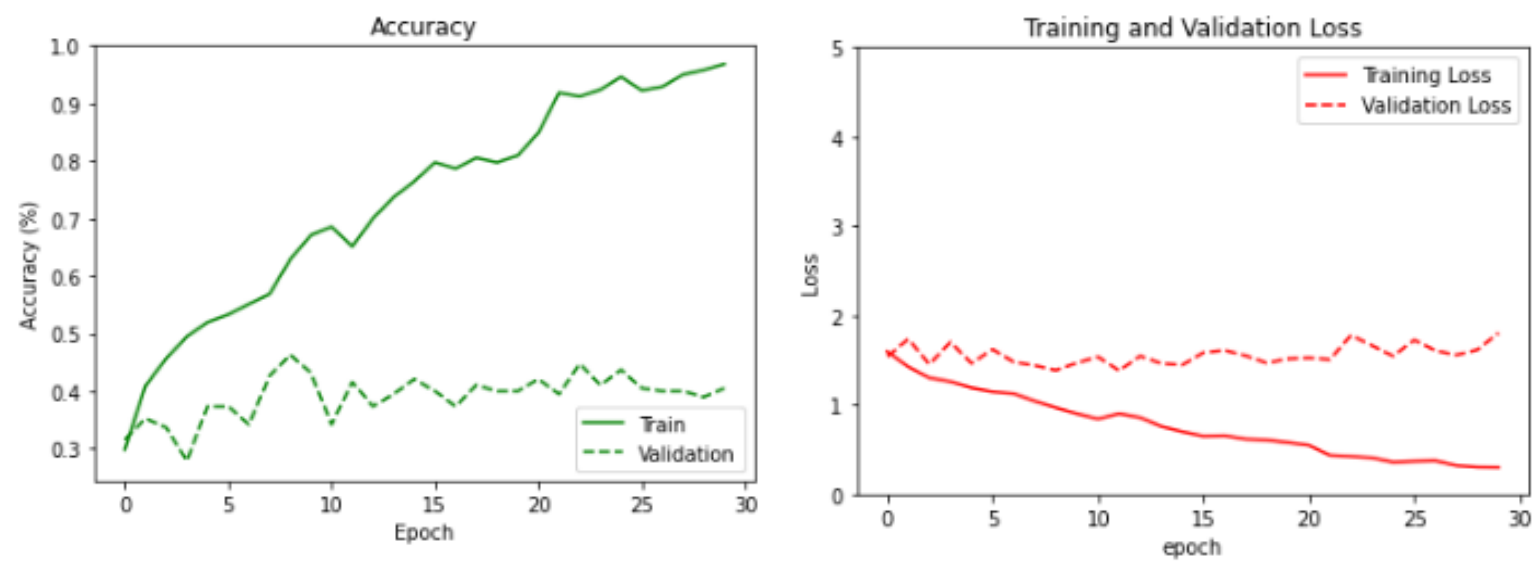

Gambar 7. Grafik akurasi dan loss dari model terbaik pada Multilayer Perceptron 

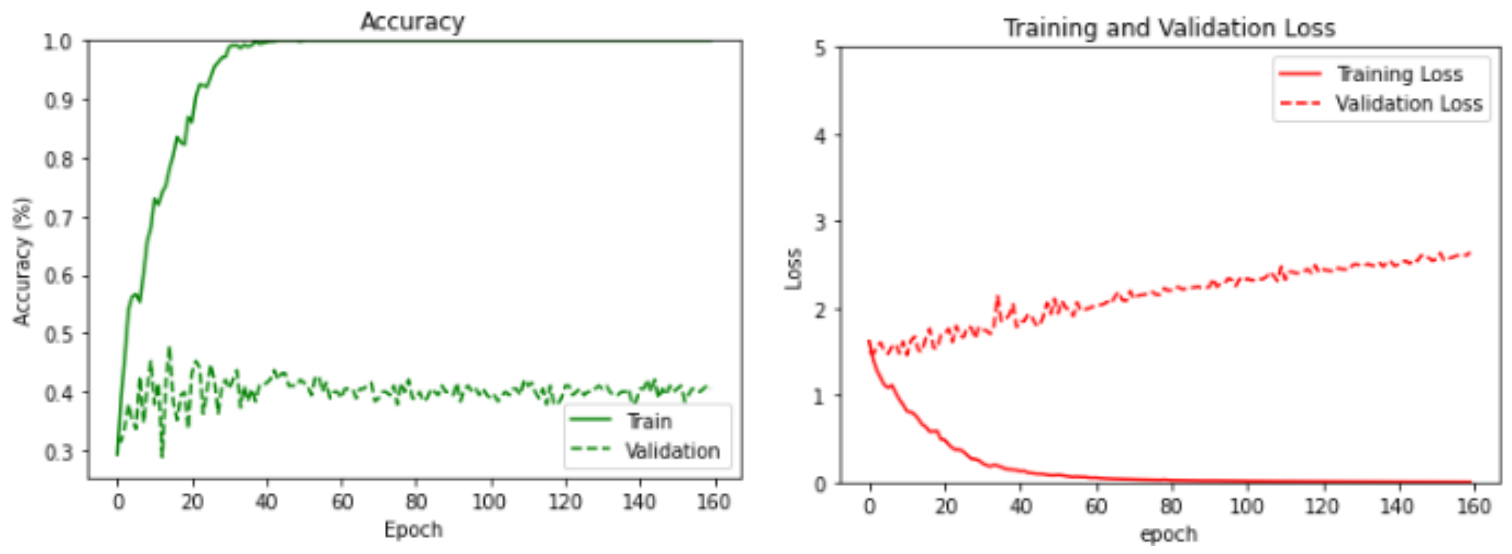

Gambar 8. Grafik akurasi dan loss dari model terbaik setelah konfigurasi hyperparameter pada Multilayer Perceptron

Tabel 4. Hasil pengujian sistem dengan dua dataset

\begin{tabular}{ccc}
\hline \multirow{2}{*}{ Jenis akurasi } & \multicolumn{2}{c}{ Tingkat akurasi (\%) } \\
\cline { 2 - 3 } & $\begin{array}{c}\text { Dataset citra tersedia } \\
\text { dari internet }\end{array}$ & $\begin{array}{c}\text { Dataset citra dari } \\
\text { IP Camera }\end{array}$ \\
\hline Akurasi latih & 97.45 & 100 \\
\hline Akurasi validasi & 46.32 & 92.86 \\
\hline
\end{tabular}

Tabel 4 menyajikan hasil dari pengujian dalam nilai persentase akurasi latih dan akurasi validasi yang diperoleh terhadap kedua dataset yang digunakan, yaitu dataset citra yang tersedia dari internet serta dataset citra dari IP camera. Berdasarkan hasil pengujian, diperoleh nilai akurasi latih $97.45 \%$ dan akurasi validasi sebesar $46.32 \%$ untuk citra yang dikumpulkan dari internet, sedangkan nilai $100 \%$ dan $92.86 \%$ untuk masing-masing akurasi latih dan akurasi validasi untuk dataset citra dari IP camera. Perbedaan hasil yang signifikan terjadi akibat beberapa kondisi yang tidak konsisten terhadap lokasi, penempatan objek, dan latar belakang citra pada dataset dari internet. Sementara untuk citra pada dataset IP Camera, pengambilan video dapat diatur dengan lebih konsisten dalam hal lokasi, pencahayaan, dan kualitas citra yang direkam karena dikontrol oleh tim peneliti.

Beberapa hasil analisis terhadap hasil pengujian mencakup penyesuaian konfigurasi tidak menghasilkan perubahan yang signifikan terhadap kemampuan model. Ukuran batch 8 menghasilkan akurasi latih yang sedikit lebih tinggi daripada model dengan ukuran batch 32 dan batch 64, sementara ukuran batch 32 menghasilkan akurasi validasi yang sedikit lebih tinggi daripada model dengan ukuran batch 8 dan batch 64. Terjadi kemungkinan bahwa sudah mencapai batas maksimal kemampuannya. Selain itu, keterbatasan jumlah data latih dan banyaknya noise dalam setiap data citra membuat model sulit untuk mendapatkan hasil yang maksimal.

\section{KESIMPULAN DAN SARAN}

Sistem pengenal aktivitas manusia dari rekaman video menggunakan Multilayer Perceptron yang diusulkan dapat memberikan hasil yang memuaskan. Hasil pengujian aplikasi menjamin fungsi dan fitur yang ada pada program aplikasi dapat berfungsi sesuai dengan rancangan. Program 
aplikasi yang dirancang dapat menerima file video, melakukan pencacahan citra, melakukan deteksi aktivitas yang terjadi, serta menghasilkan $\log$ aktivitas sesuai timestamp. Model Multilayer Perceptron yang dikembangkan juga telah mampu melakukan pendeteksian aktivitas manusia dengan baik, terutama untuk kondisi lokasi dan latar belakang yang konsisten. Tingkat akurasi tertinggi yang diperoleh sistem untuk dataset citra yang dikumpulkan dari internet adalah $100 \%$ untuk akurasi latih dan $47.89 \%$ untuk akurasi validasi, serta $100 \%$ dan $92.86 \%$ tingkat akurasi latih serta akurasi validasi untuk dataset citra yang dikumpulkan dengan IP Camera.

Untuk penelitian selanjutnya, dapat dilakukan pengambilan data aktivitas manusia tidak hanya berupa video atau gambar, namun dapat menggunakan sensor kinetik, seperti accelerometer dan gyroscope untuk memperoleh data pergerakan aktivitas manusia yang lebih akurat.

\section{REFERENSI}

Agarap, A.F. (2020). Deep Learning Using Rectified Linear Units (ReLU). ArXiv, abs/1803.08375.

Franco, A., Magnani, A., Maio, D. (2020). A Multimodal Approach for Human Activity Recognition Based on Skeleton and RGB Data. Pattern Recog. Letters, 131, 293-299.

Gaglio, S., Re, G.L., Morana, M. (2014). Human Activity Recognition Process Using 3-D Posture Data. IEEE Trans. on Human-Mac. Sys., 45(5), 586-597.

Hussain, Z., Sheng, Q.Z., Zhang, W. (2020). A Review and Categorization of Techniques on Device-Free Human Activity Recognition. J. Netw. Comput. Appl., 167, 102738.

Komang, M.G.A., Nasution, S.M., Ratna, A.N. (2019). Human Activity Recognition Using Skeleton Data and Support Vector Machine. J. Phys.Conf.Ser., 1192, 012044.

Murad, A. and Pyun, J-Y. (2017). Deep Recurrent Neural Networks for Human Activity Recognition. Sensors, 17(11), 2556.

Prastika, K. and Lina (2020). Application of Individual Activity Recognition in the Room Using CNN Alexnet Method. Tarumanagara Int. Conf. on the Appl. of Tech. and Eng. - IOP Conf. Ser.: Mater. Sci. Eng., Jakarta, 3-4 Agustus 2020, 1007.

Ronao, C.A. and Cho, S-B. (2016). Human Activity Recognition with Smartphone Sensors using Deep Learning Neural Network. Expert Sys. with Appl., 59, 235-244.

Srivastava, R. and Pandey, M. (2017). Human Activity Recognition by Analysis of Skeleton Joint Position in Internet of Things (IOT) Environment. Indian J. Sci. and Tech., 10(16), 19.

Trinh, H.A., Truong, Q.P., Nguyen, T.H., Tran, T.M. (2015). Support Vector Machine Algorithm for Human Fall Recognition Kinect-based Skeletal Data. $2^{\text {nd }}$ National Foundation for Science and Technology Development Conference on Information and Computer Science (NICS), Ho Chi Minh City, 16 September 2015, 202-207.

Wan, S., Qi, L., Xu, X., Tong, C., Gu, Z. (2019). Deep Learning Models for Real-time Human Activity Recognition with Smartphones. Mobile Netw. Appl., 25, 743-755. 